\title{
Kontaktwechselwirkung einer Rohrleitung mit der Reparaturbandage aus einem Kompositwerkstoff
}

\section{Holm Altenbach, Dmitriy}

A. Beschetnikov, Gennadiy I. Lvov, Konstantin Naumenko \& Vladimir

\section{G. Sukiasov}

\section{Forschung im Ingenieurwesen} Engineering Research

ISSN 0015-7899

Volume 78

Combined 1-2

Forsch Ingenieurwes (2014) 78:59-67 DOI 10.1007/s10010-014-0173-y

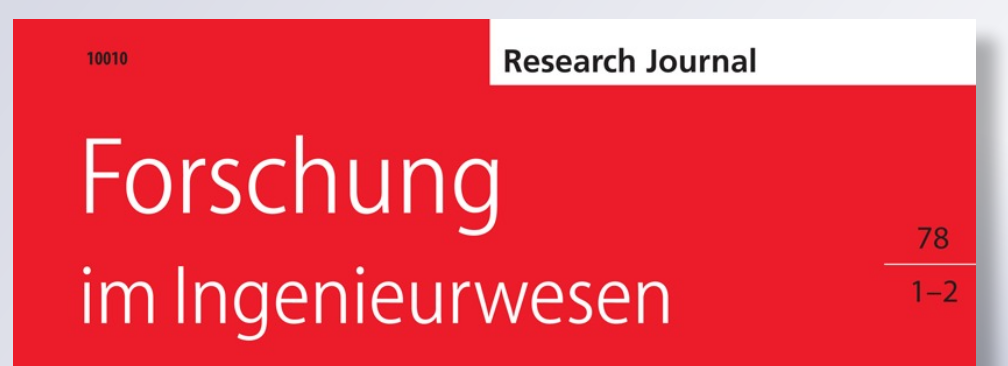

Engineering Research

E) SpringerVieweg

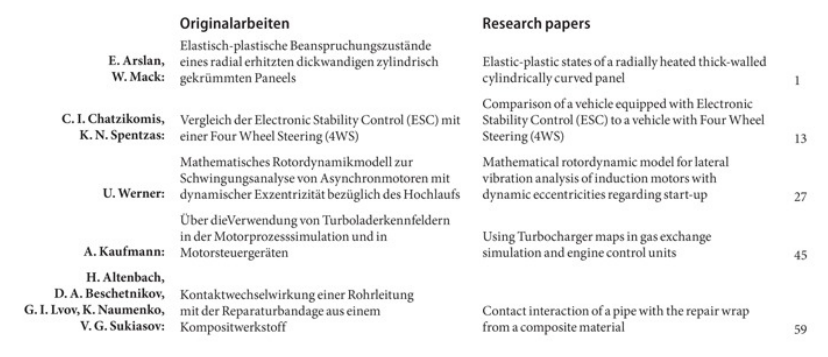

Springer 
Your article is protected by copyright and all rights are held exclusively by SpringerVerlag Berlin Heidelberg. This e-offprint is for personal use only and shall not be selfarchived in electronic repositories. If you wish to self-archive your article, please use the accepted manuscript version for posting on your own website. You may further deposit the accepted manuscript version in any repository, provided it is only made publicly available 12 months after official publication or later and provided acknowledgement is given to the original source of publication and a link is inserted to the published article on Springer's website. The link must be accompanied by the following text: "The final publication is available at link.springer.com". 


\title{
Kontaktwechselwirkung einer Rohrleitung mit der Reparaturbandage aus einem Kompositwerkstoff
}

\author{
Holm Altenbach · Dmitriy A. Beschetnikov · Gennadiy I. Lvov · Konstantin Naumenko · \\ Vladimir G. Sukiasov
}

Eingegangen: 30. Oktober 2013 / Online publiziert: 12. April 2014

(C) Springer-Verlag Berlin Heidelberg 2014

Zusammenfassung In der vorliegenden Arbeit wird die Kontaktaufgabe über die Wechselwirkung einer langen Zylinderschale mit einer koaxialen zylindrischen Bandage aus einem Verbundwerkstoff untersucht. Der Verbundwerkstoff wird als ein homogenes orthotropes Material mit bekannten effektiven elastischen Eigenschaften modelliert. Basierend auf der klassischen Schalentheorie werden die Grundgleichungen für die Kontaktaufgabe sowie allgemeine Lösungen für die Durchbiegungen und Schnittgrößen formuliert. Die unbekannten Integrationskonstanten sowie die Kontaktfläche werden numerisch mit Hilfe des Programmpakets Maple ermittelt. Drei charakteristische Längen der Bandage, bei denen der Übergang von einem Kontaktschema der Wechselwirkung zu einem anderen erfolgt, wurden ermittelt. Es wurde festgestellt, dass die Änderung des Innendrucks nicht zum Übergang von einem Kontaktschema zu einem anderen führt. Der Charakter der Kontaktwechselwirkung wird durch geometrische Parameter der Verbindung und elastische Materialeigenschaften der Schale und der Bandage bestimmt.

Contact interaction of a pipe with the repair wrap from a composite material

Abstract In the present work the contact interaction of a long cylindrical shell with a coaxial cylindrical wrap made

H. Altenbach $(\bowtie) \cdot$ K. Naumenko

Institut für Mechanik, Otto-von-Guericke-Universität Magdeburg,

PF 4120, 39016 Magdeburg, Deutschland

E-Mail: holm.altenbach@ovgu.de

D. A. Beschetnikov · G. I. Lvov · V. G. Sukiasov

Lehrstuhl Dynamik und Festigkeit von Maschinen, „Kharkover

Polytechnisches Institut“", Nationale Technische Universität,

ul. Frunze 21, 61002 Kharkov, Ukraine of a composite material is investigated. The composite material is modeled as a homogeneous orthotropic medium with known effective elastic properties. Based on the classical shell theory governing equations for the contact problems and general solutions to the deflections and internal forces are formulated. The unknown integration constants and the contact surface area are determined numerically using the software package Maple. Three characteristic lengths of the wrap, for which the transition from one contact mode to another takes place, have been determined. It was found that the change in the internal pressure does not affect the transition between the contact modes. The nature of the contact interaction is determined by the geometric parameters of the contact pair and elastic material properties of the shell and the repair wrap.

\section{Formelzeichen}

$c_{i j} \quad$ Komponenten des Steifigkeitstensors

$D \quad$ Biegesteifigkeit der Schale

$D_{b} \quad$ Biegesteifigkeit der Bandage

E Elastizitätsmodul

$h \quad$ Dicke der Schale

$h_{b} \quad$ Dicke der Bandage

$L \quad$ Länge der Bandage

$L^{*} \quad$ Kritische Länge des ersten Kontaktschemas

$L^{* *} \quad$ Kritische Länge des zweiten Kontaktschemas

$l \quad$ Länge der Kontaktfläche

$M \quad$ Biegemoment

$p \quad$ Innendruck

$p_{k} \quad$ Kontaktdruck

$Q \quad$ Querkraft

$R \quad$ Radius der Schalenmittelfläche

$R_{b} \quad$ Radius der Bandagenmittelfläche

$w \quad$ Durchbiegung der Schale 